\title{
Ciência e destruição
}

\section{CARLOS MALFERRARI}

\section{O dedo de Crátilo}

ODOS Nós conhecemos a observação de Heráclito de que não é possível mergulhar duas vezes no mesmo rio. Crátilo, discípulo seu e mestre de L Platão, foi ainda mais longe e afirmou que não é possível mergulhar sequer uma vez no mesmo rio, visto que o fluxo constante de todas as coisas sensíveis torna-as incognoscíveis. Na realidade, seria impossível até pronunciar o nome das coisas ou pensar sobre o rio sem uma sintaxe e uma semântica correspondentemente ágeis. Foi essa perspectiva radical que acabou sendo imortalizada por Aristóteles, que escreveu que Crátilo "chegou por fim a pensar que não era possível dizer coisa alguma e se contentava em mover o dedo". ${ }^{1}$

Se a mudez da filosofia perante as coisas em si é consequência inevitável do choque entre a fluidez dos fenômenos e a fixidez da linguagem, os movimentos do dedo de Crátilo parecem indicar que, não obstante, alguma coisa sobre alguma coisa pode, de alguma maneira, ser dita. O dedo de Crátilo deve ser visto, portanto, como símbolo da revolta humana contra o estado de ignorância a que estamos condenados - e símbolo também da esperança humana de que algum tipo de conhecimento é possível, mesmo que para obtê-lo seja preciso interromper a eterna mobilidade das coisas.

A esse conhecimento possível das coisas damos hoje o nome de ciência e podemos dizer que a história da ciência é a história do longo esforço da humanidade para "estancar" o rio heraclitiano, ainda que momentaneamente, a fim de conhecê-lo.

\section{Para onde vai um rio parado?}

Copérnico estancou o movimento perfeito dos astros e descobriu que a Terra se movia. Newton estancou por um instante o movimento dos corpos e descobriu em cada uma de suas partículas constitutivas uma força inexorável que chama para si todas as outras partículas. Hubble estancou o tempo e seus olhos se abriram para o momento da origem de tudo, o Big Bang. Darwin estancou a hipotética interferência da deidade no planeta e descobriu o segredo da transmutação biológica.

Em outras palavras, rios parados geram conhecimento. De suas águas plácidas emanam conteúdos novos e fatos inéditos podem ser previstos, pois o estado de repouso assegura que os fenômenos se repetirão. Assim, após um longo período ao longo do qual a religião predicou a primazia do movimento e reservou a imobilidade a Deus, a ciência floresceu.

Por mais "etéreo", todavia, que seja o estudo das forças mecânicas e ele- 
tromagnéticas, por mais "não carnais" que sejam as leis da termodinâmica, "a natureza é rubra em presas e garras" ${ }^{2}$ como disse Tennyson, referindo-se à brutalidade essencial da vida. Talvez por isso mesmo, quando o método indutivo é aplicado ao estudo de seres vivos, ele se torna também brutal e sangrento, por mimetismo, de tal modo que a imobilização seletiva do objeto de estudo - o "estancar o rio" - só se torna possível se o ser vivo for transformado em ser morto.

William Harvey só foi descobrir a circulação sanguínea depois de destrinçar um sem-número de porcos vivos. Ele próprio foi antecedido por certo Matteo Colombo, que vivisseccionava cães e outros animais com esse intuito na mesma Universidade de Pádua onde Galileu estudaria os corpos celestes (e ficaria cego de tanto perscrutar o Sol).

Ou seja, embora rios parados estivessem gerando conhecimento novo, nesses casos eles o faziam à custa da destruição do objeto de estudo.

Inabalável diante de tudo isso, porém, o método experimental continuava sendo aperfeiçoado e aplicado às ciências biológicas, até ser legitimado como a metodologia padrão da medicina a partir de Claude Bernard ${ }^{3}$ ou, em outras palavras, até que o establishment científico aceitasse que a vivissecção é imprescindível para o avanço médico. Curiosamente, contudo, a inquietação ética acerca desse mais polêmico dos processos foi mínima - um silêncio provocado talvez pelo enorme volume de novos conhecimentos adquiridos.

Seja como for, o próprio sucesso dessa prática acabou criando um dilema, pois o único critério definitivo para confirmar a aplicabilidade das pesquisas em animais ao estudo e resolução de problemas médicos humanos é a realização de experimentos vivisseccionistas em seres humanos. Esse passo derradeiro na busca do conhecimento, ainda um tabu mas uma consequência inevitável do método indutivo aplicado à medicina, teria de aguardar o surgimento de uma conjuntura sociopolítica favorável - a qual, aliás, não tardaria.

O importante é que o precedente estava aberto e que a destruição do objeto de estudo tornou-se um procedimento não só justificado, mas também fecundo para adquirir novos conhecimentos.

\section{O paradigma da destruição na física}

No final do século XIX, verificou-se que o rio heraclitiano era muito mais caudaloso do que se poderia imaginar. As descobertas dos raios X por Roentgen em 1895, da radioatividade por Becquerel em 1896 e do elétron por Thomson em 1897 comprovaram que não se podia confiar sequer na estabilidade aparente da matéria. Estancar esse rio para estudá-lo não seria nada fácil.

Como vimos, entretanto, um precedente fora aberto. Se a destruição do objeto de estudo havia sido tão fértil para a biologia, não seria talvez igualmente fecunda para descrever a roda-viva do universo subatômico?

Assim, em 1919, Rutherford aplicou a técnica de destruir para conbecer e tornou-se a primeira pessoa a cindir, por ato deliberado, um átomo, usando o 
método ainda "natural" de bombardeá-lo com as partículas alfa de uma substância radioativa existente. Os resultados foram maravilhosos: o átomo deixou de existir e deu lugar ao próton. Em 1932, sob sua orientação, usou-se pela primeira vez um acelerador de partículas para cindir o átomo por meios inteiramente artificiais. Também em 1932, Chadwick, aplicando a mesma técnica de destruir para conhecer, descobriu o nêutron, que Lise Meitner usaria sete anos mais tarde para realizar a primeira fissão do núcleo atômico. Seis anos depois, em Alamogordo, a explosão do primeiro artefato atômico soltaria sobre o planeta um tipo inédito de energia.

Causa certo espanto, nessa breve história da física nuclear, o fato de que nenhum de seus protagonistas expressasse preocupação, ou mesmo curiosidade, diante dos resultados digamos "metafísicos" de suas pesquisas, embora estivessem lidando com o mais íntimo âmago da matéria, com pontos fora do espaço e do tempo onde homem ou deus algum jamais pusera os olhos ou as mãos.

A despeito de a fissão nuclear não ser um processo que ocorra espontaneamente na natureza, ${ }^{4}$ ninguém se perguntou: "É lícito fazermos isso? Quais podem ser as consequências de aniquilarmos o próprio âmago da matéria?". Nenhuma comissão de sábios foi formada para averiguar as implicações éticas das novas formas de destruição, nenhum congresso foi convocado para debater se o esfacelamento da matéria num ponto do cosmos teria efeitos - e quais - em outros pontos do cosmos.

Por sua vez, considerando que a vivissecção animal ou mesmo humana não instigou nem instiga hoje a menor inquietação ética, não chega a surpreender que ninguém se preocupasse com a extinção de uns pequeninos grânulos amorfos de matéria.

Diz-se que alguns cientistas que trabalharam no Projeto Manhattan tiveram graves problemas de consciência, mas só depois que as bombas explodiram em Hiroshima e Nagasaki. Diz-se também que Oppenheimer, às vésperas da explosão da Trinity, o primeiro artefato atômico, chegou a considerar a possibilidade de que a reação em cadeia não ficasse confinada ao plutônio, se estendesse para os outros elementos e acabasse por destruir o cosmos numa grande bola de fogo. Diz-se ainda que às $5 \mathrm{~h} 30$ da manhã daquele 15 de julho de 1945 , quando surgiu das entranhas da matéria uma luz que não era deste mundo, Oppenheimer teria pensado com seus botões: "Agora tornei-me Shiva, o destruidor de mundos", numa referência à divindade hindu que, além de destruir, também cria mundos.

As coisas seguiram seu curso pouco natural e chegamos hoje ao Grande Colisor de Hádrons, o maior aparato de destruição de objetos de estudo já criado. Tamanho descaso com a existência não pode senão transbordar para outros planos.

\section{Embriões, fetos, abortos e o sonho da vida eterna}

A conjuntura sociopolítica favorável que a biologia moderna aguardava para liberar a vivissecção humana foi, é claro, o nazismo, com seus famigerados 
campos de experimentos sociobiológicos em Buchenwald e Auschwitz, e sua exportação em massa de cientistas e pesquisadores para o Ocidente após a guerra.

Que tipo de medicina pode advir de uma física e uma biologia assoladas pelo paradigma da destruição, de um contexto científico desprovido de inquietação ética e sem nenhum temor sobrenatural, de uma filosofia ainda cartesiana que, como seu fundador, aspira à vida eterna?

Conta-se que Cleópatra idealizou um experimento para verificar a teoria segundo a qual o embrião masculino leva 40 dias e o feminino 80 dias para maturar. Ela fez que os tribunais condenassem suas criadas à morte e, em segui$\mathrm{da}$, ordenou que fossem fecundadas e submetidas a operações para abrir-lhes o útero em momentos específicos da gravidez. Em outras palavras, Cleópatra, essa protocientista extemporânea, replicou nosso velho e consagrado método científico e estancou o rio da gestação para descobrir os segredos dos embriões.

Passados mais de dois mil anos, com todo o cabedal ético de Alamogordo e Buchenwald nas costas, a ciência começa a se voltar de modo sistemático para o mesmo projeto de pesquisa. Por trás de cada avanço em tratamentos baseados em células-tronco embrionários, existe um vasto comércio de embriões, fetos e blastócitos inteiros ou em pedaços. Em 1998, por exemplo, o último ano de que tenho notícias, ${ }^{5}$ um embrião inteiro extraído por aspiração no primeiro trimestre de gestação custava US\$ 220 por espécime fresco e US\$260 por espécime congelado. Em pedaços, valiam muito mais, num intrigante exemplo de partes maiores que o todo: o pâncreas de um embrião com menos de oito semanas custava US\$ 100, o mesmo preço de um rim (com ou sem glândula adrenal) de um feto com mais de oito semanas.

Quaisquer que possam ser os benefícios vindouros desse tipo de pesquisa, é certo que historiadores do futuro ficarão pasmos com a autofagia explícita da nossa sociedade, se perguntarão o que poderia ter nos levado a embarcar nesse barco furado e é provável que atribuam esse desvio à nossa húbris e à adoção de um método científico que pressupõe a destruição do seu objeto de estudo.

\section{A língua de Crátilo}

A controvérsia medieval a respeito do caráter nominalista ou realista dos universais nos soa graciosa e antiquada, mas isso apenas porque somos hoje radicalmente nominalistas. Do mesmo modo, a controvérsia na Grécia antiga a respeito do caráter convencionalista ou naturalista da linguagem também nos soa pitoresca, mas isso apenas porque, como Sócrates, somos radicalmente convencionalistas. Ou, como disse Niels Bohr, "é um equívoco achar que a função da física seja descobrir como a natureza funciona; a física refere-se àquilo que dizemos sobre a natureza".

$\mathrm{O}$ velho Crátilo, ao contrário de Wittgenstein, preferiu calar-se diante da impossibilidade de dizer alguma coisa. O jovem Crátilo, porém, era um naturalista e acreditava que "há um nome correto, por natureza, para cada ente" e que esse nome "tem a função de instruir" - mais ou menos como no livro de 
Gênesis, ${ }^{7}$ segundo o qual o nome de cada coisa foi dado pelo próprio homem primevo arquetípico.

Nós, porém, fomos expulsos do paraíso e não temos como voltar a ser naturalistas. Entretanto, metaforicamente falando, a chave do bom conhecimento talvez esteja em apreender o nome verdadeiro de cada coisa, que só pode se dar a conhecer se a coisa não for destruída.

A ciência tomou para si o dedo de Crátilo e descartou a sua língua. É mais do que hora de corrigir essa falha.

\section{Notas}

1 Metafísica IV, c. 5. 101a 5-15.

2 [Man,] who trusted God was love indeed / And love Creation's final law / Tho' Nature, red in tooth and claw / With ravine, shriek'd against his creed. In Memorian, 55.

3 Bernard chegou a publicar em 1865 uma "Introdução ao estudo da experimentação humana".

4 Alguns cientistas hoje acreditam, embora ainda não provem, que ocorra fissão nuclear no processo de formação das supernovas. O caráter genesíaco da fissão nesse caso apenas confirma a gravidade do estatuto semiontológico desse processo.

5 Alberta Report, v.26, n.32, 23 Aug. 1999.

6 Platão, Crátilo 428d.

7 "Deus modelou do solo todas as feras e todas as aves e as conduziu ao homem para ver como ele as chamaria; e cada qual devia levar o nome que o homem lhe desse" (Gênesis, $2: 19)$.

RESUMO - Este ensaio vê a ciência como o longo esforço da humanidade para estancar o rio heraclitiano das coisas em perpétuo movimento. Disso adviria conhecimento. Todavia, a aplicação do método indutivo ao estudo de seres vivos exige que esses também sejam estancados - mortos, no limite. A história da biologia dá abundantes exemplos disso, e, modernamente, fetos e embriões têm sido vítimas desse paradigma. $\mathrm{Na}$ física, desde o final do século XIX, o estancamento vem gerando igual destruição. O filósofo Crátilo, discípulo de Heráclito e mestre de Platão, na velhice silenciou-se diante da impossibilidade do conhecimento, mas na juventude era um naturalista que acreditava que existe um "nome" correto na natureza para cada ente. $\mathrm{O}$ artigo propõe que, a fim de não contribuir para a autofagia da sociedade contemporânea, a ciência precisaria deixar de destruir seus objetos de estudo e aprender a compreender o nome verdadeiro desses.

PALAVRAS-CHAVE: Ciência, Destruição, Crátilo, Vivissecção, Aborto, Ética.

ABSTRACT - This essay sees science as humanity's longstanding effort to stanch the Heraclitean river of things in perpetual motion, from which knowledge would emanate. The application of the inductive method to the study of living things, however, requires 
that these also be stanched - killed, ultimately. The history of biology provides abundant examples and, in modern times, fetuses and embryos have been victims of this paradigm. In physics, since the late nineteenth century, the stanching has engendered like destruction. In his old age, the philosopher Cratylus, disciple of Heraclitus and master of Plato, chose to silence himself in the face of the impossibility of knowledge, but when young he was a naturalist who believed that there is a proper "name" in Nature for each being. This article proposes that, to avoid contributing to the autophagy of contemporary society, science must cease destroying its objects of study and learn to understand their real name.

KEYWORDS: Science, Destruction, Cratylus, Vivisection, Abortion, Ethics.

Carlos Malferrari é tradutor, formado em Filosofia pela USP. @ - cmalferrari@uol.com.br

Recebido em 4.8.2009 e aceito em 21.9.2010. 